\title{
Tranexamic Acid and Major Spine Surgery: Trends and Controversies
}

Sergey Pisklakov*, Haitham Ibrahim and Liang Huang

Department of Anesthesiology, Montefiore Medical Center, The University Hospital for Albert Einstein College of Medicine, USA

${ }^{*}$ Corresponding author: Sergey Pisklakov, Department of Anesthesiology, Montefiore Medical Center, The University Hospital for Albert Einstein College of Medicine, USA, Tel: 917847 1077; E-mail: spisklak@montefiore.org

Received date: August 20, 2017; Accepted date: August 30, 2017; Published date: September 4, 2017

Copyright: $\odot$ Pisklakov S, et al. This is an open-access article distributed under the terms of the Creative Commons Attribution License, which permits unrestricted use, distribution, and reproduction in any medium, provided the original author and source are credite.

\begin{abstract}
The beneficial role and efficacy of Tranexamic Acid in reducing perioperative blood loss and blood transfusion requirements in spine surgery is being established. Tranexamic Acid is an antifibrinolytic agent traditionally used to lessen perioperative blood loss. Tranexamic Acid can be administered orally, intramuscularly, intravenously or topically. Tranexamic Acid studies in spine surgery have limited patient enrolment. Most of the reported studies have mixed results and difficult to interpret. The efficacy of antifibrinolytic agents is evident in a wide variety of surgical procedures: liver transplantation, obstetrics and gynaecology, trauma and orthopaedic surgical procedures. The effect of Tranexamic Acid on the occurrence of thromboembolic events, strokes, myocardial ischemia, seizures and mortality has not been adequately assessed and remains uncertain. A number of possible complications reported. In this review, we analyze the efficacy and safety profile of perioperative Tranexamic Acid with the exclusion of cardiac surgery and a focus on major spinal surgery.
\end{abstract}

\section{Introduction}

Excessive bleeding often complicates spine surgery. This may result in increased morbidity and mortality [1,2]. The amount of blood loss depends on many factors. The extent of a surgical procedure is the principal cause of a blood loss during spine surgery. Perioperative coagulation dysfunction is also an important factor leading to an excessive blood loss during lengthy spinal surgeries. Tranexamic Acid (TA) is safely used for the prevention of blood transfusion for major joint replacement procedures [3,4]. The benefit and safety of tranexamic TA in patients undergoing major spinal fusion is not completely established. Nevertheless, TA appears to have a potential role in the management of spinal surgery. Identifying patients at risk plays paramount importance in preventing excessive blood loss $[5,6]$. The role of a surgeon cannot be overestimated. Optimal positioning to minimize epidural venous bleeding, including intraoperative normovolemic hemodilution, cell salvaging, minimization of a surgical invasiveness, staging of a procedure and administration of various antifibrinolytic agents is utilized with various success to lessen perioperative blood loss in patients undergoing spine surgery. What method is the most effective, safest or advantageous remains unclear $[7,8]$.

Surgical hemostasis is obviously the most crucial blood losspreventing factor [9]. Nevertheless, topical and systemic pharmacological agents are evidently of an additional merit $[10,11]$. Judicious surgical hemostasis and procoagulants agents are complementary in managing perioperative hemorrhage [5,12]. Systemic procoagulants agents, such as aprotinin, $\varepsilon$-aminocaproic acid (EACA) and TA are being used. These agents are proved to be effective in prophylaxis of perioperative blood loss and its treatment [13]. Efficacy of Desmopressin and Recombinant VIIa factor classically used perioperatively in patients with pre-existing coagulopathy is also controversial $[14,15]$. Overall the efficacy of antifibrinolytic agents was evident in a wide variety of surgical procedures: liver transplantation [16], obstetrics and gynecology [17], trauma [7,18] and orthopedic surgical procedures [19].
Though TA studies in spine surgery have limited patient enrolment, the beneficial role and efficacy of TA in reducing perioperative blood loss and blood transfusion requirements in spine surgery is continuously evolving. The safety of TA is still unclear and remains inadequately investigated $[20,21]$. The incidence of side effects and complications of TA use in spinal surgery needs to be further explored. The effective dosage of TA in spine surgery is not completely established. Reported data supports a wide range of different TA regimens [20]. There is still a need for a standard peri-operative administration of antifibrinolytic agents. It is ultimately important to identify patients with active history of thromboembolic disease (DVT, $\mathrm{PE}$ and etc.) and those at risk for thrombosis (like those with thrombophilia, immobility, atrial fibrillation, mechanical valve prostheses, hyperhomocysteinaemia, increased plasma level of coagulation factors, chronic inflammatory diseases, chronic hormonotherapy, pregnancy, smocking, oral contraceptives intake and Factor C and Factor S deficiency) and advanced age [22]. Each patient's risks and benefits assessment needs to be established individually as TA use advocated in a wide range of conditions (such as spinal fusions, spinal stenosis correction, and trauma) or discouraged (such as tumor cases). In this review, we analyze the efficacy and safety profile of perioperative TA with the exclusion of cardiac surgery and a focus on major spinal surgery.

\section{What is Tranexamic Acid?}

TA is an antifibrinolytic agent traditionally used to lessen perioperative blood loss. TA can be administered orally, intramuscularly, intravenously or topically $[23,24]$. TA is a synthetic analog of the aminoacid lysine. It is in a way similar to EACA, which is a synthetic lysine analog. EACA competitively inhibits the conversion of plasminogen to plasmin and directly inhibits the activity of plasmin, integral to fibrin lysis. TA affects fibrinolysis in the same manner as EACA but is significantly more active. TA competitively inhibits plasminogen activation to plasmin by binding to plasminogen specific sites. This prevents fibrin degradation [25] and clot breakdown. TA 
Page 2 of 8

also improves the impaired platelet function, which contributes to the blood-saving effect [26].

\section{Question of a Perioperative TA Dosage}

The peri-operative dosage of TA poorly established and not well standardized. It varies considerably for different surgeries and medical conditions. The original manufacturer of TA, Pfizer, recommends different dosages. As per insert, the dosage is different for variety surgical interventions. For dental surgery in patients with (hemophilia A) coagulopathy it is recommended that immediately before surgery $10 \mathrm{mg}$ per $\mathrm{kg}$ of body weight should be given intravenously followed by $25 \mathrm{mg}$ per $\mathrm{kg}$ of body weight is given orally three to four times daily for six to eight days after surgery. For adult cardiac surgery: after induction of anesthesia and prior to skin incision, the manufacturer recommends the administration of a loading dose of $15 \mathrm{mg} / \mathrm{kg}$ of TA, followed by an infusion of $4.5 \mathrm{mg} / \mathrm{kg} / \mathrm{hour}$ for the duration of the surgery; up to $0.6 \mathrm{mg} / \mathrm{kg}$ of this dose may be added to the priming volume of the heart-lung machine. For adult knee arthroplasty, the administration of $15 \mathrm{mg} / \mathrm{kg}$ TA is recommended prior to the release of the tourniquet, followed by two repeat bolus injections of $15 \mathrm{mg} / \mathrm{kg}$ at $8 \mathrm{~h}$ intervals; the last bolus dose should be administered 16 hours after the initial dose. For adult hip arthroplasty, the administration of 15 $\mathrm{mg} / \mathrm{kg}$ of TA is recommended immediately prior to skin incision, followed by 2 repeat boluses of $15 \mathrm{mg} / \mathrm{kg}$ at 8 hour intervals. The last bolus dose is to be administered 16 hours after the initial dose [27].

There is evolving evidence about the comparable efficacy of a topical TA to the intravenous route. Topical route may potentially minimize the chances of possible perioperative adverse effects of the intravenous TA administration (like thromboembolic, renal or neurological adverse events). A randomized controlled trial exhibit comparable efficacy of a topical TA in decreasing blood loss in total hip and knee arthroplasty and heart surgery [28-30].

\section{Controversy of TA efficacy in blood loss and blood transfusion reduction}

Spinal surgery is often bloody. Blood transfusions are not uncommon. Antifibrinolytic agents, including TA, could be valuable adjuncts to perioperative hemorrhage management. Evidence suggests that TA reduces the need for transfusion. The efficacy of TA varies. It depends on the type of surgery and many other factors. The evidence that TA reduces blood transfusion in surgical patients is available. TA may reduce overall blood loss by up to one-third [31]. TA was compared to placebo in randomized clinical studies. Reduced perioperative blood loss was established in a variety of surgical procedures, including intracranial surgery [32], trauma [7,20], cardiac surgery with or without cardiopulmonary bypass [33], total hip and knee replacement [34], cranyosynostosis surgery [35], gastrointestinal endoscopy procedures [36], ear-nose-and-throat procedures [37], prostatectomy [38], and spinal surgeries [39-42], caesarean sections and vaginal deliveries [43]. Oral TA has been used with success as a treatment for heavy menstrual bleeding [17].

TA was proved to be effective in trauma care. In a multi center study TA decreased the need to massive blood transfusion and improved survival rate in bleeding injury patients [44]. TA is incorporated into US Military practice guidelines for tactical combat casualty care [21]. Army forces' experience showed TA's efficacy in the pre-hospital setting without evacuation delays [45]. Retrospective analysis 896 injured personnel database in Afghanistan, reported significant mortality reduction with the use of TA [46]. CRASH-2 trial established that TA administration reduces death, vascular occlusive events and blood transfusion in trauma patients with significant blood loss [47,48].

The majority of research on this topic has significant limitations. The present role of TA in reducing perioperative loss and blood transfusion requirements in spine surgery is still not fully elucidated. Insufficient patient enrollment and mixed results are common [49]. TA reduces the percentage of spinal surgery patients' blood transfusion need [50-52]. It reduces transfusion requirements at a higher degree than desmopressin [22] and proved to be equally effective as EACA in intraoperative hemorrhage reduction [53]. TA was compared to aprotinin for blood loss control during spinal surgery and was found to be equally effective [54].

Spinal deformity surgery involves almost unavoidable and sometimes significant perioperative blood loss risk [55]. Intraoperative antifibrinolytic agents reduce this risk [41,42,45,56-62]. Aprotinin, TA and EACA are effective in reducing bleeding and blood transfusion reduction during spinal surgery $[53,63,64]$. Nevertheless, one study reported that EACA had a greater effect on reducing blood transfusions as the complexity of surgery increased [65], another one reported aprotinin being more effective than EACA [64]. A 2009 systematic review of the literature and meta-analysis conducted to identify all randomized controlled trials of aprotinin, TA, and EACA involving children undergoing cardiac or scoliosis surgery failed to show evidence that compared with aprotinin, TA was more effective in reducing blood loss in major pediatric surgery [66]. In retrospective review of 230 patients undergoing single stage posterior spinal fusion for idiopathic scoliosis TA administration reduced the percentage of patients with idiopathic scoliosis received blood transfusion [67]. In another study TA reduced blood loss by $41 \%$ compared with placebo in pediatric patients undergoing elective scoliosis surgery [56]. TA decreased intraoperative blood loss in the study of intraoperative blood loss and transfusion requirements in adolescent idiopathic scoliosis patients undergoing posterior spinal fusion by a single surgeon [68]. In 2012, a retrospective review of prospectively collected data of 84 pediatric scoliosis corrections, TA significantly reduced intraoperative blood loss associated with posterior spinal fusion [57]. Recently published randomized trial showed a $33.4 \%$ reduction in the intraoperative estimated blood loss and a $41 \%$ reduction in total blood loss when TA was used intraoperatively for posterior lumbar surgery for spondylolisthesis [69].

The hemostatic effect of TA is a dose-dependent. A prospective dose-ranging study is required to determine the optimal dose for pediatric patients with idiopathic scoliosis [70]. TA showed to reduce blood loss and hemotransfusion requirements during thoracolumbar trauma surgery [71] and during posterior lumbar surgeries [72]. The prophylactic efficacy of TA in spinal surgery is neither well studied nor established. The administration of a prophylactic low dose of TA failed to have a significant effect on transfusion requirements in patients undergoing spinal fixation surgery [73].

TA failed to improve hemostasis during surgical treatment of metastatic spine tumors [74]. It showed to be effective in perioperative blood loss reduction, primarily through a reduction in postoperative blood loss, in cervical laminoplasty [75]. Interestingly, TA may also influence inflammatory pathways. This could be TA's additional benefit. Studies on this role of TA are controversial and indecisive [76]. TA was shown to reduce overall hospital stay after knee replacement surgery [77]. Intraoperative Viscoelastic Hemostatic Assay (VHA) may be a useful tool to assess the need for TA. A recently published 
Page 3 of 8

systematic review and meta-analysis [78] showed a significant reduction of allogenic blood products transfusion rates when VHA was used. Targeted administration of TA in those with proved hyper fibrinolysis could allow a more effective approach to reduce perioperative blood loss.

\section{Questions and Controversy of Complications Associated with TA Usage}

The effect of TA on the occurrence of thromboembolic events, strokes, myocardial ischemia, seizures and mortality has not been adequately assessed and remains uncertain (39). A number of possible complications and events were reported (summarized in a Table 1).

\section{Thromboembolic events}

Intraoperatively, when antifibrinolytics agents are given, postoperatively fibrinogen levels tend to be increasingly higher [79]. It brings a concern, that TA may cause a higher incidence of postoperative thromboembolic events. In the UK, Japan and EU TA is not advised in patients with a history of thromboembolic disease or extreme vigilance is strongly recommended. Active thromboembolic disease is a contraindication for TA use in the EU and the UK [80]. Pulmonary embolism (PE) [81] and deep venous thrombosis (DVT) [82] has been reported with TA use. Though prospective controlled trials, retrospective studies and case-series in children and adults [57,83-86] including those targeted at spine surgeries [65,72,87] showed low incidence of vascular thrombosis, these trials and studies were not designed specifically to evaluate the incidence of thrombosis. Majority of these clinical trials and randomized studies were done on patients undergoing joint replacements. There are no targeted retrospective spinal surgery database studies, which could possibly explain this issue. Most of the clinical trials analyzing thromboembolic complications of TA in surgery are either conflicting or inadequately powered to make a definitive conclusion [21,50]. A number of randomized studies showed that compared to placebo, ant fibrinolytic agents reducing bleeding and need for transfusion in joint replacement orthopaedic surgery $[34,88]$ and spine surgery without increased risk of myocardial infarction, stroke, deep vein thrombosis or pulmonary embolism. 2016 meta-analysis of TA use in bilateral total knee arthroplasty did not show an increase in occurrence of DVT [88]. Though, Claeys et al. reported an increase in the rate of DVT when TA was used [89]. Ker et al. assessed 129 trials done between 1972 and 2011, totalling 10488 patients. Their data source was the Cochrane central register of controlled trials, Medline, and Embase, the World Health Organization International Clinical Trials Registry Platform, and the reference lists of relevant articles. While reducing the probability of receiving a blood transfusion by a third, the effect of TA on myocardial infarction, stroke, deep vein thrombosis and pulmonary embolism was uncertain [36]. Gillette et al. retrospectively reviewed 2046 patients from 2007 to 2009 and who underwent primary total hip arthroplasty or total knee arthroplasty and received TA, comparing three chemical regimens (aspirin alone, warfarin and dalteparin). The primary outcome measures were venous TE events, including symptomatic deep vein thrombosis and pulmonary embolism, and arterioocclusive events, including myocardial infarction and cerebrovascular accident. For aspirin, warfarin, and dalteparin, the rates of symptomatic deep venous thrombosis and nonfatal pulmonary embolism were similar. Authors saw a low complication rate when using TA as a blood conservation modality during primary THA and TKA with less aggressive thromboprophylactic regimens such as aspirin alone and dose-adjusted warfarin [90]. Duncan et al. [91] retrospectively reviewed 13,262 cases of elective total knee arthroplasty and total hip arthroplasty, and found that the odds of postoperative venous thromboembolism and 30-day mortality were unchanged with TA administration. Alshryda et al. conducted a systematic review and meta-analysis of 19 randomized controlled trials analyzing TA usage complications in total knee replacement. Considerable patient heterogeneity slights the interpretation of the study with no sufficient evidence indicating an increased risk of deep-vein thrombosis or pulmonary embolism caused by TA [92]. In Baldus et al. study of aprotinin and TA in controlling blood loss during lumbar pedicle subtraction osteotomy in adults, no major intraoperative complications like postoperative cases of seizures, myocardial infarction, stroke, deep venous thrombosis or pulmonary embolism were identified [52]. Currently there is no strong evidence that TA leads to increased rate of thromboembolic events. Future studies multicenter randomized studies are needed to clarify the exact role and safety of TA in spine surgery.

\section{Seizures and Renal Complications}

TA is associated with postoperative seizures in patients with renal disease $[93,94]$. Cases of acute renal cortical necrosis after TA use have been described $[95,96]$.

Perhaps, doses of TA should be reduced in patients with mild to moderate renal insufficiency [93] or may be TA needs to be avoided in these patients [64]. In patients with renal insufficiencies or at a high risk for developing TA related adverse events, a VHA-guided administration of TA may be a wise approach [64]. TA is contraindicated in the EU in patients with severe renal failure because of the risk of accumulation. Multifocal myoclonus was reported after TA infusion [97]. TA is known to lower the seizure threshold in animals [98]. A nationwide data base study in japan 2016, Maeda et al retrospective cohort study showed a significant increase in seizures risk with use of TA in pediatric patients who underwent cardiac surgery [99]. The use of high-dose TA in older patients in conjunction with cardiopulmonary bypass and open-chamber cardiac surgery [100-103] was associated with clinical seizures, which could be due to ischemic brain injury [104]. These seizures are more pronounced in those with perioperative renal disease [105]. A one-year follow up of 1188 cardiac surgery patients found a significantly higher incidence of seizures among those who received TA [13]. Another multivariate analysis of 11529 cardiac surgery patients revealed a strong association between postoperative seizures and TA. TA was also reported as an independent predictor of postoperative seizures [106]. TA is structurally similar to the inhibitory neurotransmitter glycine. Since reduced function of glycine receptors causes seizures, TA may possibly inhibit the activity of glycine receptors $[96,107]$ and may have intrinsic proconvulsive properties. When compared to EACA in a clinical retrospective study, TA was found to cause seizures more often [108]. High dose TA appears to be an independent seizure predictor [109]. Seizures may also develop as a result of TA overdose [110]. 


\begin{tabular}{|c|c|c|}
\hline Adverse Events & Reference & Characteristics of Events \\
\hline \multicolumn{3}{|l|}{ Thrombo-embolic events } \\
\hline Pulmonary Embolism & [81] & $\begin{array}{l}\text { Reported case of a pulmonary embolism in a patient with an acquired Factor VIII inhibitor, who was on a } \\
\text { prophylactic TA }\end{array}$ \\
\hline \multirow[t]{3}{*}{ Deep Vein Thrombosis } & {$[82]$} & Multiple reports of deep venous thrombosis sited \\
\hline & [88] & $\begin{array}{l}\text { Authors report that TA did not increase the occurrence of deep vein thrombosis in bilateral total knee } \\
\text { arthroplasty patients }\end{array}$ \\
\hline & [89] & $\begin{array}{l}\text { In this prospective, placebo-controlled, double blind, randomized clinical trial, authors investigated the } \\
\text { effect of a single preoperative bolus dose of tranexamic acid }(15 \mathrm{mg} / \mathrm{kg}) \text { on perioperative blood losses } \\
\text { and packed cell transfusion requirements in patients scheduled for primary unilateral total hip } \\
\text { replacement surgery. Compression ultrasonography on the } 10 \text { th postoperative day was positive for deep } \\
\text { venous thrombosis in } 3 \text { patients who were on TA group ( } 17 \text { patients were screened) and negative in all } \\
\text { patients of the placebo group ( } 18 \text { patients screened). The rate was } 3 / 17 \text { or about } 17 \% \text {. }\end{array}$ \\
\hline \multicolumn{3}{|l|}{$\begin{array}{l}\text { Unclear evidence to support the } \\
\text { increased risk of Stroke \& Ml }\end{array}$} \\
\hline & [36] & $\begin{array}{l}\text { Seven double-blind randomized trials on tranexamic acid vs. placebo were analyzed. Data from three of } \\
\text { the included trials suggested that tranexamic acid did not significantly increase the risk of } \\
\text { thromboembolic disease. }\end{array}$ \\
\hline & & $\begin{array}{l}\text { Authors reported Incidence that Myocardial infarction rate was } 2 \text { out of } 522 \text { patients in TA group vs } 2 \text { out } \\
\text { of } 526 \text { in placebo group. Stroke was reported in } 1 \text { out of } 522 \text { on TA and in } 2 \text { out of } 526 \text { patients on } \\
\text { placebo. }\end{array}$ \\
\hline & [52] & $\begin{array}{l}\text { Though the primary concern with the use of TXA is the potential for an increased risk of thromboembolic } \\
\text { complications such as peri-operative myocardial infarction, stroke, deep vein thrombosis, and pulmonary } \\
\text { meta-analysis demonstrates that TXA was not associated with increased incidence of such } \\
\text { thromboembolic complications. }\end{array}$ \\
\hline \multicolumn{3}{|l|}{ Neurologic events } \\
\hline \multirow[t]{4}{*}{ a. Seizures } & [13] & $\begin{array}{l}\text { Retrospective analysis of } 1188 \text { consecutive patients, which showed an incidence of seizure of } 4.6 \% \text { in } \\
\text { patients receiving tranexamic acid } v s 1.2 \% \text { in the aprotinin group }(P<0.001) .\end{array}$ \\
\hline & [102] & $\begin{array}{l}\text { The study aimed to examine the association between TA use and adverse events as seizures, } \\
\text { thromboembolism, and renal dysfunction) in a pediatric cardiac surgery population using Japan's national } \\
\text { inpatient database. Propensity-matched analysis showed that the proportion of seizures was significantly } \\
\text { higher in those on TA ( } 1.6 \% \text { versus. Authors concluded that TA is associated with a significantly } \\
\text { increased risk of seizures. }\end{array}$ \\
\hline & [103] & $\begin{array}{l}\text { In this case series, } 7 \text { patients receiving TA described over the course of } 18 \text {-month period who had open- } \\
\text { chamber cardiac surgery and developed seizures in the postoperative period. There was an increased } \\
\text { incidence in a group compared to those who did not receive TA }(0.66 \% \text { versus } 0 \% ; P<.05) \text {. }\end{array}$ \\
\hline & {$[27,28,109]$} & $\begin{array}{l}\text { Authors report that the use of higher doses of TXA has been associated with a higher incidence of } \\
\text { seizures }(2.7 \% \text { versus } 7.6 \%)\end{array}$ \\
\hline Multifocal Myoclonus & {$[100]$} & $\begin{array}{l}\text { Myoclonus reported in a patient on chronic ambulatory peritoneal dialysis for adult polycystic kidney } \\
\text { disease who was transfused with two units of packed cells and started on oral tranexamic acid } 500 \mathrm{mg} \\
\text { four times daily. }\end{array}$ \\
\hline \multicolumn{3}{|l|}{ Renal events } \\
\hline \multirow[t]{2}{*}{ Acute cortical Necrosis. } & [97] & The author reported a case of acute cortical necrosis associated with TA use. \\
\hline & [98] & $\begin{array}{l}\text { The author reports one case of renal acute cortical necrosis induced by TA in a patient with Hemophilia } \\
\text { A. }\end{array}$ \\
\hline \multicolumn{3}{|l|}{ Ophthalmic events } \\
\hline $\begin{array}{l}\text { Central retinal artery occlusion \& } \\
\text { disturbance in color vision }\end{array}$ & [112] & A case of central retinal occlusion with a color vision disturbance reported \\
\hline b. Central venous stasis retinopathy & [113] & $\begin{array}{l}\text { Report on central venous stasis retinopathy observed in two young women following the administration of } \\
\text { oral TA for the treatment of menorrhagia. }\end{array}$ \\
\hline c. Ligneous conjunctivitis & [114] & A case report of Ligneous Conjunctivitis \\
\hline
\end{tabular}


Page 5 of 8

\section{Other complications}

Adverse allergic reactions may also occur with a TA infusion [111]. Ligneous conjunctivitis [112], toxic epidermal necrolysis, central venous stasis retinopathy [113], disturbances of color vision as well as central retinal artery occlusion may also result from TA infusion [112]. Though never reported in clinical trials, retinal degeneration with a high dose TA infusion was described in dogs. Ophthalmological examinations probably guarded if patient is to be receive TA.

\section{Conclusion}

Antifibrinolytic agents, including TA, could be valuable adjuncts to perioperative hemorrhage management. TA is a widely used antifibrinolytic agent. The beneficial role and efficacy of TA in reducing perioperative blood loss and need for blood transfusion is evident. TA is administered orally, intramuscularly, intravenously or topically for a wide variety of surgical procedures. The efficacy of antifibrinolytic agents is described in a wide variety of surgical procedures: liver transplantation, obstetrics and gynecology, trauma and orthopedic surgical procedures. Bleeding often complicates spine surgery. This results in increased morbidity and mortality. The extent of a surgical procedure is the principal cause of a blood loss. Perioperative coagulation dysfunction is also a factor leading to an excessive blood loss during lengthy spinal surgeries. TA efficacy in spine surgery is noticeable but most of the studies have either limited patient enrolment, mixed results or difficult to interpret. The effect of TA on the occurrence of thromboembolic events, strokes, myocardial ischemia, seizures and mortality has not been adequately assessed and needs to be elucidated. There is evidence that TA reduces the need for transfusion. The efficacy varies from study to study, depending on the type of surgery and many other factors. The benefit and safety of tranexamic TA in patients undergoing major spinal fusion is not completely established. Identifying patients at risk still plays paramount importance in preventing excessive blood loss and the role of a surgeon cannot be overestimated. Surgical hemostasis is obviously the most important. Topical and systemic pharmacological agents are of an additional merit. Judicious surgical hemostasis and procoagulant agents are complementary in managing hemorrhage.

\section{References}

1. Glance L, Dick A, Mukamel D, Fleming F, Zollo R, et al. (2011) Association between intraoperative blood transfusion and mortality and morbidity in patients undergoing noncardiac surgery. Anesthesiology 114: 283-292.

2. Lee MJ, Konodi MA, Cizik AM, Bransford RJ, Bellabarba C, et al. (2012) Risk factors for medical complication after spine surgery: a multivariate analysis of 1,591 patients. Spine J 12: 197-206.

3. Eubanks JD (2010) Antifibrinolytics in major orthopaedic surgery. J Am Acad Orthop Surg 18: 132-138.

4. Lin ZX, Woolf SK (2016) Safety, Efficacy, and Cost-effectiveness of Tranexamic Acid in Orthopedic Surgery. Orthopedics 39: 119-130.

5. Eva Y, Cheung W, Ng K, Luk K (2011) Reducing perioperative blood loss and allogeneic blood transfusion in patients undergoing major spine surgery. J Bone Joint Surg Am 93: 1268-1277.

6. Zheng F, Cammisa Jr F, Sandhu H, Girardi F, Khan S (2002) Factors predicting hospital stay, operative time, blood loss, and transfusion in patients undergoing revision posterior lumbar spine decompression, fusion, and segmental instrumentation. Spine 27: 818-824.

7. Cap A, Baer D, Orman J, Aden J, Ryan K, et al. (2011) Tranexamic acid for trauma patients: a critical review of the literature. J Trauma 71: S9S14.
8. Raw DA, Beattie JK, Hunter JM (2003) Anaesthesia for spinal surgery in adults. Br J Anaesth 91: 886-904.

9. Nuttall G, Horlocker T, Santrach P, Oliver Jr W, Dekutoski M, et al. (2000) Predictors of blood transfusions in spinal instrumentation and fusion surgery. Spine 25: 596-601.

10. Jenis L, Hsu W, O’Brien J, Whang P (2013) Recent advances in the prevention and management of complications associated with routine lumbar spine surgery. J Bone Joint Surg Am 95: 944-950.

11. Fraser IS, Porte RJ, Kouides PA, Lukes AS (2008) A benefit-risk review of systemic haemostatic agents. Drug Safety 31: 217-230.

12. Szpalski M, Gunzburg R, Sztern B (2005) An overview of blood-sparing techniques used in spine surgery during the perioperative period. Haemostasis in Spine Surgery, 18-27.

13. Ortmann E, Besser M, Klein A (2004) Antifibrinolytic Agents in Current Anaesthetic Practice. Survey of Anesthesiology 58: 192-193.

14. Friederich P, Henny C, Messelink E, Geerdink M, Keller T, et al. (2003) Effect of recombinant activated factor VII on perioperative blood loss in patients undergoing retropubic prostatectomy: a double-blind placebocontrolled randomised trial. Lancet 361: 201-205.

15. Wademan BH, Galvin SD (2014) Desmopressin for reducing postoperative blood loss and transfusion requirements following cardiac surgery in adults. Interact Cardiovasc Thorac Surg 18: 360-370.

16. Makwana J, Paranjape S, Goswami J (2010) Antifibrinolytics in liver surgery. Indian J Anaesth 54: 489-495.

17. Archer D, Fraser I (2013) An expert review and commentary on the efficacy and safety of tranexamic acid for the treatment of heavy menstrual bleeding. Expert Review of Obstetrics \& Gynecology 8: 499-511.

18. Nardi G, Agostini V, Rondinelli B, Russo E, Bastianini B, et al. (2015) Trauma-induced coagulopathy: impact of the early coagulation support protocol on blood product consumption, mortality and costs. Critical Care 19: 83.

19. Ozier Y, Schlumberger S (2006) Pharmacological approaches to reducing blood loss and transfusions in the surgical patient. Can J Anaesth 53: S21S29.

20. McCormack PL (2012) Tranexamic acid: a review of its use in the treatment of hyperfibrinolysis. Drugs 72: 585-617.

21. Pusateri A, Weiskopf R, Bebarta V, Butler F, Cestero R, et al. (2013) Tranexamic acid and trauma: current status and knowledge gaps with recommended research priorities. Shock 39: 121-126.

22. Previtali E, Bucciarelli P, Passamonti SM, Martinelli I (2011) Risk factors for venous and arterial thrombosis. Blood Transfus 9: 120-138.

23. Ipema HJ, Tanzi MG (2012) Use of topical tranexamic acid or aminocaproic acid to prevent bleeding after major surgical procedures. Ann Pharmacother 46: 97-107.

24. Alshryda S, Mason J, Sarda P, Nargol A, Cooke N, et al. (2013) Topical (Intra-Articular) Tranexamic Acid Reduces Blood Loss and Transfusion Rates Following Total Hip ReplacementA Randomized Controlled Trial (TRANX-H). J Bone Joint Surg Am 95: 1969-1974.

25. Porte R, Leebeek F (2002) Pharmacological strategies to decrease transfusion requirements in patients undergoing surgery. Drugs 62: 2193-2211.

26. Weber C, Görlinger K, Byhahn C, Moritz A, Hanke A, et al. (2011) Tranexamic acid partially improves platelet function in patients treated with dual antiplatelet therapy. Eur J Anaesthesiol 28: 57-62.

27. PRODUCT MONOGRAPH -CYKLOKAPRON ${ }^{\infty}$ Tranexamic acid. 500 $\mathrm{mg}$ tablets, $500 \mathrm{mg} / 5 \mathrm{~mL} \& 1000-\mathrm{mg} / 10 \mathrm{~mL}$ solution for injection. Pfizer New Zealand Ltd. P O Box 3998. Auckland, New Zealand, 1140. DATE OF PREPARATION: 25 February 2013.

28. Chen T, Chen Y, Jiao J, Wang Y, Qian L, et al. (2017) Comparison of the effectiveness and safety of topical versus intravenous tranexamic acid in primary total knee arthroplasty: a meta-analysis of randomized controlled trials. J Orthopaedic Surg Res 12: 11. 
Page 6 of 8

29. Patel J, Prajapati M, Patel H, Gandhi H, Deodhar S, et al. (2017) Topical and low-dose intravenous tranexamic acid in cyanotic cardiac surgery. Asian Cardiovasc Thorac Ann 25: 118-122.

30. Ker K, Prieto-Merino D, Roberts I (2013) Systematic review, metaanalysis and meta-regression of the effect of tranexamic acid on surgical blood loss. Br J Surg 100: 1271-1279.

31. Hillman J, Fridriksson S, Nilsson O, Yu Z, Säveland H, et al. (2002) Immediate administration of tranexamic acid and reduced incidence of early rebleeding after aneurysmal subarachnoid hemorrhage: a prospective randomized study. J Neurosurg 97: 771-778.

32. Zufferey P, Merquiol F, Laporte S, Decousus H, Mismetti P, et al. (2006) Do antifibrinolytics reduce allogeneic blood transfusion in orthopedic surgery. Anesthesiology 105: 1034-1046.

33. Koster A, Faraoni D, Levy JH (2015) Antifibrinolytic Therapy for Cardiac Surgery: An Update. Anesthesiology 123: 214-221.

34. Choi W, Irwin M, Samman N (2009) The effect of tranexamic acid on blood loss during orthognathic surgery: a randomized controlled trial. J Oral Maxillofac surg 67: 125-133.

35. Dadure C, Sauter M, Bringuier S, Bigorre M, Raux O, et al. (2011) Intraoperative tranexamic acid reduces blood transfusion in children undergoing craniosynostosis surgery: a randomized double-blind study. Anesthesiology 114: 856-861.

36. Gluud L, Klingenberg S, Langholz S (2008) Systematic review: tranexamic acid for upper intestinal bleeding. Aliment Pharmacol Ther 27: 752-758.

37. George A, Kumar R, Kumar S, Shetty S (2011) A randomized control trial to verify the efficacy of pre-operative intra venous tranexamic acid in the control of tonsillectomy bleeding. Indian J Otolaryngol Head Neck Surg 63: 20-26.

38. Crescenti A, Borghi G, Bignami E, Bertarelli G, Landoni G (2011) Intraoperative use of tranexamic acid to reduce transfusion rate in patients undergoing radical retropubic prostatectomy: double blind, randomised, placebo controlled trial. BMJ 343: d5701.

39. Wong J, Beheiry H, Rampersaud Y, Lewis S, Ahn H, et al. (2008) Tranexamic Acid reduces perioperative blood loss in adult patients having spinal fusion surgery. Anesth Analg 107: 1479-1486.

40. Elgafy H, Bransford R, McGuire R, Dettori J, Fischer D (2010) Blood loss in major spine surgery: are there effective measures to decrease massive hemorrhage in major spine fusion surgery? Spine 35: S47-S56.

41. Badeaux J, Hawley D (2014) Effectiveness of intravenous tranexamic acid administration in managing perioperative blood loss in patients undergoing spine surgery: a systematic review. The JBI Database of Systematic Reviews and Implementation Reports 12: 284-314.

42. Suksamosorn P, Suarjui J, Lewsirirat S (2011) Tranexamic Acid in Reducing Perioperative Blood Loss in Lumbar Spinal Stenosis Surgery. J Orthop Surg 35: 1-7.

43. Peitsidis P, Kadir RA (2011) Antifibrinolytic therapy with tranexamic acid in pregnancy and postpartum. Expert Opin Pharmacother 12: 503-516.

44. Balvers K, van Dieren S, Baksaas-Aasen K, Gaarder C, Brohi K, et al. (2017) Combined effect of therapeutic strategies for bleeding injury on early survival, transfusion needs and correction of coagulopathy. $\mathrm{Br} \mathrm{J}$ Surg 104: 222-229.

45. Lipsky AM, Abramovich A, Nadler R, Feinstein U, Shaked G, et al. (2014) Tranexamic acid in the prehospital setting: Israel Defense Forces' initial experience. Injury 45: 66-70.

46. Morrison J, Dubose J, Rasmussen T, Midwinter M (2012) Military application of tranexamic acid in trauma emergency resuscitation (MATTERs) study. Arch Surg 147: 113-119.

47. Williams-Johnson J, McDonald A, Strachan G, Williams E (2010) Effects of tranexamic acid on death, vascular occlusive events, and blood transfusion in trauma patients with significant haemorrhage (CRASH-2): a randomised, placebo-controlled trial. West Indian Medical Journal 59: 612-624.

48. Roberts I, Shakur H, Afolabi A, Brohi K, Coats T, et al. (2011) The importance of early treatment with tranexamic acid in bleeding trauma patients: an exploratory analysis of the CRASH-2 randomised controlled trial. Lancet 377: 1096-1101.

49. Sander M, Spies C, Martiny V, Rosenthal C, Wernecke K, et al. (2010) Mortality associated with administration of high-dose tranexamic acid and aprotinin in primary open-heart procedures: a retrospective analysis. Crit Care 14: R148.

50. Ker K, Edwards P, Perel P, Shakur H, Roberts I (2012) Effect of tranexamic acid on surgical bleeding: systematic review and cumulative meta-analysis. BMJ 344: e.3054.

51. Yang B, Li H, Wang D, He X, Zhang C, et al. (2013) Systematic review and meta-analysis of perioperative intravenous tranexamic acid use in spinal surgery. PLoS One 8: e55436.

52. Choi HY, Hyun SI, Kim KJ, Jahng TA, Kim HJ (2017) Effectiveness and Safety of Tranexamic Acid in Spinal Deformity Surgery. J Korean Neurosurg Soc 60: 75-81.

53. Boenigk K, Verma K, Hoelscher C, Huncke K, Lonner B, et al. (2011) The efficacy of antifibrinolytics at reducing blood loss in major spine surgery: A prospective randomized comparison of tranexamic acid, aminocaproic acid, and placebo: 6AP4-7. Eur J Anaesthesiol 28: 90.

54. Baldus C, Bridwell K, Lenke L, Okubadejo G (2010) Can We Safely Reduce Blood Loss During Lumbar Pedicle Subtraction Osteotomy Procedures Using Tranexamic Acid or Aprotinin?: A Comparative Study With Controls. Spine 35: 235-239.

55. Good CR, Auerbach JD, O'Leary PT, Schuler TC (2011) Adult spine deformity. Curr Rev Musculoskelet Med 4: 159-167.

56. Sethna N, Zurakowski D, Brustowicz R, Bacsik J, Sullivan L, et al. (2005) Tranexamic acid reduces intraoperative blood loss in pediatric patients undergoing scoliosis surgery. Anesthesiology 102:727-732.

57. Dhawale A, Shah S, Sponseller P, Bastrom T, Neiss G, et al. (2012) Are antifibrinolytics helpful in decreasing blood loss and transfusions during spinal fusion surgery in children with cerebral palsy scoliosis? Spine 37: E549-E555.

58. Yagi M, Hasegawa J, Nagoshi N, Iizuka S, Kaneko S, et al. (2012) Does the intraoperative tranexamic acid decrease operative blood loss during posterior spinal fusion for treatment of adolescent idiopathic scoliosis? Spine 37: E1336-E1342.

59. Ra' Kerry K, Rahman K, Min W, Nakamura Y, Zebala L, et al. (2011) High Dose Tranexamic Acid Reduces Blood Loss in Complex Pediatric Spine Deformity Surgery: PAPER\# 111 In Spine Journal Meeting Abstracts 113.

60. Shapiro F, Zurakowski D, Sethna N (2007) Tranexamic acid diminishes intraoperative blood loss and transfusion in spinal fusions for Duchenne muscular dystrophy scoliosis. Spine 32: 2278-2283.

61. Moguilevitch M, Balikai C, Sarwahi V, Smolinski J, Cajust M (2012) Blood loss reduction in scoliosis surgery. A retrospective comparative study of aminocapronic and tranexamic acid: 6AP2-2. Eur J Anaesthesiol 29: 95.

62. Urban M, Beckman J, Gordon M, Urquhart B, Boachie-Adjei O (2001) The efficacy of antifibrinolytics in the reduction of blood loss during complex adult reconstructive spine surgery. Spine 26: 1152-1156.

63. Kuklo TR, Owens BD, Polly DW Jr (2003) Perioperative blood and blood product management for spinal deformity surgery. Spine J 3: 388-393.

64. Colomina M, Bagó J, Vidal X, Mora L, Pellisé F (2009) Antifibrinolytic therapy in complex spine surgery: a case-control study comparing aprotinin and tranexamic acid. Orthopedics 32: 91.

65. Gill B, Chin Y, Levin A, Feng D (2008) The Use of Antifibrinolytic Agents in Spine SurgeryA Meta-Analysis. J Bone Joint Surg Am 90: 2399-2407.

66. Schouten E, van de Pol A, Schouten A, Turner N, Jansen N, et al. (2009) The effect of aprotinin, tranexamic acid, and aminocaproic acid on blood loss and use of blood products in major pediatric surgery: a metaanalysis. Pediatr Crit Care Med 10: 182-190.

67. Ngo K, Khemani R, Choi P, Ross P (2013) Tranexamic Acid Reduces PRBC Transfusion after Posterior Spine Surgery for Idiopathic Scoliosis from the Operating Room to Post-Operative Day Four. J Anesthesia Clinic Res 4: 338. 
Page 7 of 8

68. Lykissas M, Crawford A, Chan G, Aronson L, Al-Sayyad M (2013) The effect of tranexamic acid in blood loss and transfusion volume in adolescent idiopathic scoliosis surgery: a single-surgeon experience. J Child Orthop 7: 245-249.

69. Shi H, Ou Y, Jiang D, Quan Z, Zhao Z, et al. (2017) Tranexamic acid reduces perioperative blood loss of posterior lumbar surgery for stenosis or spondylolisthesis: A randomized trial. Medicine (Baltimore) 96: e5718.

70. Grant J, Howard J, Luntley J, Harder J, Aleissa S, et al. (2009) Perioperative blood transfusion requirements in pediatric scoliosis surgery: the efficacy of tranexamic acid. J Pediatr Orthop 29: 300-304.

71. Garg B, Dhatt S, Chakraborty S (2012) Use of Single-Dose Tranexamic Acid to Reduce Blood Loss in Operative Thoracolumbar Trauma: A Comparative Study. Spine J 12: S93

72. Qi W, Liu J, Fan R, Chen Y, Yu H, et al. (2013) Tranexamic acid reduces postoperative blood loss of degenerative lumbar instability with stenosis in posterior approach lumbar surgery: a randomized controlled trial. Eur Spine J 22: 2035-2038.

73. Farrokhi M, Kazemi A, Eftekharian H, Akbari K (2011) Efficacy of prophylactic low dose of tranexamic acid in spinal fixation surgery: a randomized clinical trial. J Neurosurg Anesthesiol 23: 290-296.

74. Bednar DA, Bednar VA, Chaudhary A, Farrokhyar F (2006) Tranexamic acid for hemostasis in the surgical treatment of metastatic tumors of the spine. Spine 31: 954-957.

75. Tsutsumimoto T, Shimogata M, Ohta H, Yui M, Yoda I, et al. (2011) Tranexamic acid reduces perioperative blood loss in cervical laminoplasty: a prospective randomized study. Spine 36: 1913-1918.

76. Rosemarijn R, Weijer S, de Vos A, Pater J, Meijers J, et al. (2004) Inhibition of plasmin activity by tranexamic acid does not influence inflammatory pathways during human endotoxemia. Arterioscler Thromb Vasc Biol 24: 483-488.

77. Ismail K, Moll N, Koch L, Swanson K, Walsh G (2012) Intra-operative tranexamic acid reduces blood loss and length of hospital stay after unilateral knee replacement surgery: 6AP2-5. Eur J Anaesthesiol 29: 95-96.

78. Fahrendorff M, Oliveri R, Johansson P (2017) The use of viscoelastic haemostatic assays in goal-directing treatment with allogeneic blood products - A systematic review and meta-analysis. Scand J Trauma Resusc Emerg Med 25: 39.

79. Thompson G, Florentino-Pineda I, Armstrong D, Poe-Kochert C (2007) Fibrinogen levels following Amicar in surgery for idiopathic scoliosis. Spine 32: 368-372.

80. Roberts I, Kawahara T (2010) Proposal for the inclusion of tranexamic acid (anti-fibrinolytic-lysine analogue) in the WHO model list of essential medicines. Geneva, Switzerland: World Health Organization.

81. Taparia M, Cordingley F, Leahy M (2002) Pulmonary embolism associated with tranexamic acid in severe acquired haemophilia. Eur J Haematol 68: 307-309.

82. Mihalache RM, Ames PR (2012) Deep vein thrombosis, tranexamic acid, and a negative d-dimer. Clin Appl Thromb Hemost 18: 666-667.

83. Neilipovitz D, Murto K, Hall L, Barrowman N, Splinter W (2001) A randomized trial of tranexamic acid to reduce blood transfusion for scoliosis surgery. Anesth Analg 93: 82-87.

84. Zhou X, Tao L, Li J, Wu L (2013) Do we really need tranexamic acid in total hip arthroplasty? A meta-analysis of nineteen randomized controlled trials. Arch Orthop Trauma Surg 133: 1017-1027.

85. Lozano M, Basora M, Peidro L, Merino I, Segur JM, et al. (2008) Effectiveness and safety of tranexamic acid administration during total knee arthroplasty. Vox Sang 95: 39-44.

86. Makhija N, Sarupria A, Kumar Choudhary S, Das S, Lakshmy R, et al. (2013) Comparison of epsilon aminocaproic acid and tranexamic acid in thoracic aortic surgery: Clinical efficacy and safety. J Cardiothorac Vasc Anesth 27: 1201-1207.

87. Weber B, Seal A, McGirr J, Fielding K (2016) Case series of elective instrumented posterior lumbar spinal fusions demonstrating a low incidence of venous thromboembolism. ANZ J Surg 86: 796-800.
88. Weng K, Zhang X, Bi Q, Zhao C (2016) The effectiveness and safety of tranexamic acid in bilateral total knee arthroplasty: A meta-analysis. Medicine 95: e4960.

89. Claeys M, Vermeersch N, Haentjens P (2007) Reduction of blood loss with tranexamic acid in primary total hip replacement surgery. Acta Chirurgica Belgica 107:397-401.

90. Gillette B, DeSimone L, Trousdale R, Pagnano M, Sierra R (2013) Low risk of thromboembolic complications with tranexamic acid after primary total hip and knee arthroplasty. Clin Orthop Relat Res 471: 150-154.

91. Duncan C, Gillette B, Jacob A, Sierra R, Sanchez-Sotelo J, et al. (2015) Venous Thromboembolism and Mortality Associated with Tranexamic Acid Use during Total Hip and Knee Arthroplasty. J Arthroplasty 30: 272-276.

92. Alshryda S, Sarda P, Sukeik M, Nargol A, Blenkinsopp J, et al. (2011) Tranexamic acid in total knee replacement: a systematic review and metaanalysis. J Bone Joint Surg Br 93: 1577-1585.

93. Good L, Peterson E, Lisander B (2003) Tranexamic acid decreases external blood loss but not hidden blood loss in total knee replacement. Br J Anaesth 90: 596-599.

94. Ido K, Neo M, Asada Y, Kondo K, Morita T, et al. (2000) Reduction of blood loss using tranexamic acid in total knee and hip arthroplasties. Arch Orthop Trauma Surg 120: 518-520.

95. Elwatidy S, Jamjoom Z, Elgamal E, Zakaria A, Turkistani A, et al. (2008) Efficacy and safety of prophylactic large dose of tranexamic acid in spine surgery: a prospective, randomized, double-blind, placebo-controlled study. Spine 33: 2577-2580.

96. Montes F, Pardo D, Carreño M, Arciniegas C, Dennis R, et al. (2012) Risk factors associated with postoperative seizures in patients undergoing cardiac surgery who received tranexamic acid: a case-control study. Ann Card Anaesth 15: 6-12.

97. Ko D, Kim T, Kim J, Gu J, Yoon B, et al. (2017) Tranexamic Acid-Induced Acute Renal Cortical Necrosis in Post-Endoscopic Papillectomy Bleeding. Clin Endosc ce.2017.021.

98. Odabas A, Çetinkaya R, Selçuk Y, Kaya H, Coskun U (2001) Tranexamicacid-induced acute renal cortical necrosis in a patient with haemophilia A. Nephrol Dial Transplant 16: 189-190.

99. Bhat A, Bhowmik D, Vibha D, Dogra M, Agarwal S (2014) Tranexamic acid overdosage-induced generalized seizure in renal failure. Saudi J Kidney Dis Transpl 25: 130- 132.

100. Hui A, Wong T, Chow K, Szeto C (2003) Multifocal myoclonus secondary to tranexamic acid. J Neurol 74: 547.

101. Schlag M, Hopf R, Redl H (2000) Convulsive seizures following subdural application of fibrin sealant containing tranexamic acid in a rat model. Neurosurgery 47: 1463-1467.

102. Maeda T, Sasabuchi Y, Matsui H, Ohnishi Y, Miyata S, et al. (2016) Safety of Tranexamic Acid in Pediatric Cardiac Surgery: A Nationwide Database Study. J Cardiothorac Vasc Anesth 31: 549-553.

103. Bell D, Marasco S, Almeida A, Rowland M (2010) Tranexamic Acid in cardiac surgery and postoperative seizures: a case report series. Heart Surg Forum 13: E257-259.

104. Merriman B, Mayson K, Sawka A, Akagami R, Flexman A (2013) Postoperative seizure in a neurosurgical patient: Should tranexamic acid be on the differential? Can J Anaesth 60: 506-507.

105. Wang C, Yang C, Chen S, Chen H, Huang M (2011) Generalized convulsion resulted in hyperammonemia during treatment with tranexamic acid for hemoptysis. Ir J Med Sci 180: 761-763.

106. Murkin J, Falter F, Granton J, Young B, Burt C, et al. (2010) High-dose tranexamic acid is associated with nonischemic clinical seizures in cardiac surgical patients. Anesth Analg 110: 350-353.

107. Keyl C, Uhl R, Beyersdorf F, Stampf S, Lehane C, et al. (2011) High-dose tranexamic acid is related to increased risk of generalized seizures after aortic valve replacement. Eur J Cardiothorac Surg 39: e114-e121.

108. Sharma V, Katznelson R, Jerath A, Garrido-Olivares L, Carroll J, et al. (2014) The association between tranexamic acid and convulsive seizures 
Citation: Pisklakov s; Ibrahim H, Huang L (2017) Tranexamic Acid and Major Spine Surgery: Trends and Controversies. J Surg Anesth 1: 107.

Page 8 of 8

after cardiac surgery: a multivariate analysis in 11529 patients Anaesthesia 69: 124-130.

109. Lecker I, Wang D, Romaschin A, Peterson M, Mazer C, et al. (2012) Tranexamic acid concentrations associated with human seizures inhibit glycine receptors. J Clin Invest 122: 4654-4666.

110. Martin K, Knorr J, Breuer T, Gertler R, MacGuill M, et al. (2011) Seizures after open heart surgery: comparison of e-aminocaproic acid and tranexamic acid. J Cardiothorac Vasc Anesth 25: 20-25.

111. Kalavrouziotis D, Voisine P, Mohammadi S, Dionne S, Dagenais F (2012) High-dose tranexamic acid is an independent predictor of early seizure after cardiopulmonary bypass. Ann Thorac Surg 93: 148-154.
112. Cravens G, Brown M, Brown D, Wass C (2006) Antifibrinolytic Therapy Use to Mitigate Blood Loss during Staged Complex Major Spine Surgery: Postoperative Visual Color Changes after Tranexamic Acid Administration. Anesthesiology 105: 1274-1276.

113. Snir M1, Axer-Siegel R, Buckman G, Yassur Y (1990) Central venous stasis retinopathy following the use of tranexamic acid. Retina 10: 181-184.

114. Song Y, Izumi N, Potts L, Yoshida A (2014) Tranexamic acid-induced ligneous conjunctivitis with renal failure showed reversible hypoplasminogenaemia. BMJ case reports. 